\title{
Germination, viability and longevity of horseweed (Conyza spp.) seeds as a function of temperature and evaluation periods
}

\author{
Dirceu Agostinetto $^{1}$ Andrés Antonio Monge $\operatorname{Vargas}^{1^{*}} \odot$ Queli Ruchel $^{1}$ \\ Jéssica Dias Gomes da Silva ${ }^{1}$ Leandro Vargas ${ }^{2}$
}

${ }^{1}$ Centro de Herbologia (CEHERB), Universidade Federal de Pelotas (UFPEL), Campus Universitário, 96160-000, Capão do Leão, RS, Brasil. E-mail: amova11@gmail.com. "Corresponding author.

${ }^{2}$ Empresa Brasileira de Pesquisa Agropecuária (EMBRAPA), Centro Nacional de Pesquisa de Trigo (CNPT), Passo Fundo, RS, Brasil.

ABSTRACT: In Brazil, horseweed is one of the most important weeds because of the resistance to herbicides and high competitive for the crops. A large of losses were reported in major crops such as soybeans, wheat and corn, where the use a no-tillage system and the herbicide resistance promote better establishment. A correct understanding of the way temperature influences germination enables the prediction of the regions with the highest potential for colonization by this weed and thus facilitates its control. The objective of this study; therefore, was to discern the ways temperature affected the germination, viability and longevity of horseweed seeds. Testing was done at 10,20 and $30^{\circ} \mathrm{C}$, while evaluation occurred on days 0, 15, 30, 45 and 60. Seeds were packed in a nylon mesh bag (5x5cm), with 10g of upland soil (Yellow Red Argissolo, sandy loam texture), placed in transparent plastic boxes at 0 to $0.5 \mathrm{~cm}$ soil depth, at the temperatures specified. Percentage of remaining seeds, first and second germination counts, abnormal seedlings, and dead, dormant, viable and non-viable seeds, were assessed. Horseweed seeds achieve secondary dormancy at 10, 20 and $30^{\circ} \mathrm{C}$, while their quality and the longevity showed damage at 20 and $30^{\circ} \mathrm{C}$ temperatures.

Key words: secondary dormancy, depth, management, seed quality.

Germinação, viabilidade e longevidade de sementes de buva (Conyza spp.) em função da temperatura e períodos de avaliação

RESUMO: No Brasil, a buva (Conyza spp.) é uma das principais plantas daninhas devido à resistência a herbicidas e alta competividade com as culturas. Esta é responsável por perdas de produtividade em culturas como soja, milho, algodão e trigo cuja implementação da semeadura direta e a resistência aos herbicidas favorecem seu estabelecimento. O conhecimento do efeito da temperatura na germinação permite prever as regiões com maior potencial de colonização e auxiliar no manejo. Assim, objetivou-se com este trabalho determinar o efeito da temperatura na germinação, viabilidade e longevidade de sementes de buva em solo de terras altas. As temperaturas testadas foram 10,20 e $30^{\circ} \mathrm{C}$ e os períodos de avaliação 0, 15, 30, 45 e 60 dias. As sementes foram acondicionadas em saco de malha de nylon (5 x $5 \mathrm{~cm})$, distribuídas em $10 \mathrm{~g}$ de solo de terras altas (Argissolo Vermelho Amarelo, de textura franco-arenosa), e, alocadas em caixas gerbox com solo a profundidade de 0 a $0,5 \mathrm{~cm}$, nas temperaturas descritas. Avaliou-se em percentagem de sementes remanescentes, primeira e segunda contagem de germinação, plântulas anormais, sementes mortas, dormentes, viáveis e não viáveis. A semente de buva atinge dormência secundária, nas temperaturas de 10,20 e $30^{\circ} \mathrm{C}$ e sua qualidade e longevidade são prejudicadas nas temperaturas de 20 e $30^{\circ} \mathrm{C}$.

Palavras-chave: dormência secundária, profundidade, manejo, qualidade de sementes.

\section{INTRODUCTION}

The horseweed (Conyza spp.) is well recognized globally as an herbicide-resistant weed and which can, according to TREZZI et al., (2014), cause up to $36 \%$ of yield loss in soybean. In southern Brazil, such losses may also be induced in other major crops as wheat and corn (VARGAS et al., 2007).

The chief species among the genus Conyza include $C$. bonariensis and C. sumatrensis, prevalent in South and Central America, as well as $C$. canadensis with a higher incidence in North America and Europe (VARGAS et al., 2007). In Brazil, while these three species were verified as resistant to the herbicide glyphosate, C. sumatrensis was also resistant to herbicide chlorimuron-ethyl (HEAP, 2016). Thus, with the curtailment of chemical use in weed management control, cultural practices play a crucial role in limiting these weeds from being dispersed to other regions and preventing them from emerging and getting established in new locations (VIDAL et al., 2007;LAZAROTO al., 2008).

Environmental conditions such as light, temperature and water potential of the soil, are factors that regulate the germination and emergence of seedlings (TREZZI et al., 2014). In horseweed, classified as a positive photoblastic seed (VIDAL et al., 2007), light and temperature act as seedpositioning sensors in the soil; therefore, seeds buried at some depths may receive insufficient 
light; and therefore, may not show any response to diurnal changes or temperature fluctuations (VIVIAN et al., 2008).

There is a controversy related to seed dormancy, some researchers reported that the horseweed seed has no dormancy (CONSTANTIN et al., 2013); however, another research informed $80 \%$ of physiological dormancy (KARLSSON \& MILBERG, 2007). Also, it was verified for this species that the seeds exhibited quiescence under conditions of insufficient light or temperature, and the germination process restarts once the limiting factor is controlled (YAMASHITA et al., 2016).

Temperature affects the water absorption rate as well as the biochemical reactions that control germination, influencing the percentage and speed of the germination process (MARCOS FILHO, 2015). From the research available, the temperature for the horseweed seed germination is between 20 and $30^{\circ} \mathrm{C}$, and $20^{\circ} \mathrm{C}$ is the optimum (WU et al., 2007). Likewise, it is important to emphasize that the horseweed seeds can germinate at temperatures below or above the optimum, as $12 / 6$ and $36 / 30^{\circ} \mathrm{C}$ which becomes crucial to its control (NANDULA et al., 2006; VIDAL et al., 2007).

Knowledge regarding to factors as the temperature range at which the horseweed seeds develop, thus becomes essential to predict the regions with the highest potential for colonization by this species; at the same time, this enables the identification of the wright time of the year for growth and development, so, certainly useful information to take management decisions for control (MAIN et al., 2006). Therefore, this study aimed to ascertain the ways that temperature influences germination, viability and longevity of the horseweed (Conyza spp.) seeds during different periods of evaluations.

\section{MATERIALS AND METHODS}

The seeds collected from four neighboring plants were taken from the EMBRAPA Clima Temperado experimental field, in the municipality of Capão do Leão, Rio Grande do

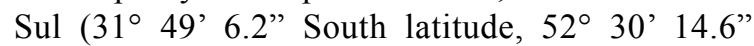
West longitude). To accomplish this, a site highly infested with horseweed was cordoned off. Growth and development of weeds were observed and about three weeks after the anthesis, seeds of mature capitula (completely open with inflorescence bearing a perfect disk of white and softly-tinted florets) were collected. Each plant was considered as a repetition, whose procedure resulted from the number of seeds needed to conduct the research. In the laboratory, using tweezers and a light stereoscope, seeds were gently removed from the capitula and only the full $(100 \%$ of the vital tissues for germination: tegument and embryo) and mature (brown tegument) seeds were selected.

Adopting a completely randomized design, the experiment was performed with four replicates and 50 seeds per each replicate. Treatments followed a factorial pattern, in which factor $\mathrm{A}$ included three temperatures $\left(10,20\right.$ and $\left.30^{\circ} \mathrm{C}\right)$ and factor $\mathrm{B}$ had five periods of evaluation $(0,15,30,45$ and 60 days).

Each experimental unit included 50 seeds mixed and distributed in $10 \mathrm{~g}$ of upland soil [Yellow-Red Argissolo, sandy-loam in texture (EMBRAPA, 2013)] packed in a nylon mesh bag $(5 \times 5 \mathrm{~cm}$ experimental unit). Next, plastic germination boxes (gerbox) were filled with the same soil but pre-moistened, to nearly threequarters of the maximum capacity. Each experimental unit was then placed in a soil-filled gerbox, with the experimental units being buried at up to $0.5 \mathrm{~cm}$ depth. Each gerbox was then sealed with film paper along the lid border. The lid was opened every 15 days and irrigated with $5 \mathrm{~mL}$ of distilled water. It was again sealed and placed in a Biological Oxygen Demand (B.O.D.), for a 12/12 hour light/dark photoperiod at 10,20 and $30^{\circ} \mathrm{C}$ temperatures.

In every evaluation seeds were removed from the experimental unit via spray washing, and the sample (soil and seeds) was placed in a funnel lined with filter paper. The sample was then left on the paper to dry for 24 hours, and then analyzed by a light stereoscope. Seeds were thus separated and extracted from the soil and the remaining seeds were obtained.

Remaining seeds were washed a second time by placing them for two minutes in distilled water and immediately submitted them to the germination test to estimate the physiological quality. The germination test was conducted using white blotter paper, which had been weighed prior and placed in the gerbox boxes with distilled water equivalent to three times its dry weight being added for moistening (BRASIL, 2009). Seeds were analyzed in a germination room at $20^{\circ} \mathrm{C}$ continuous and 24 hours of light as a photoperiod (VIDAL et al., 2007).

The following variables were assessed: remaining seeds, germination at the first and second counts, 7 and 14 days after sowing (DAS), respectively (VIVIAN et al., 2008); abnormal seedlings, dead and dormant seeds. At the first germination count only the normal seedlings (intact, healthy and with aerial parts and root developed) were counted. Identical criterion was used to assess the second count, 
taking into account the abnormal seedlings showing defects like albinism and those lacking root or shoot. Non-germinated seeds were regarded as dead (soft consistency) or dormant (hard consistency).

The percentage of the remaining seeds was estimated depending on the initial number of 50 seeds per replicate. However, calculation of the percentages of germination, abnormal seedlings, dead and dormant seeds, was dependent on the number of remaining seeds.

Once the germination test was done, the viability of the dormant seeds was assessed by applying the tetrazolium test $1.0 \%$. The seeds were first placed in a transparent glass container to which the tetrazolium solution was added. An aluminum foil covering was used to block out the light for 24 hours and the temperature was kept at $\pm 30^{\circ} \mathrm{C}$. Subsequently, using light stereoscope, each seed was analyzed and the ones in which the whole seed looked pink or carmine in color were considered viable (BRASIL, 2009). Percentages of the viable and non-viable seeds were calculated depending on the number of dormant seeds from the germination test.

The data were analyzed for normality after which the influence of the factors was assessed via the analysis of variance $(\mathrm{p} \leq 0.05)$. When statistical significance was noted, the means of the temperature variable were compared using the Duncan test $(p \leq 0.05)$ and a regression analysis was made for the variable of periods of evaluation.

\section{RESULTS AND DISCUSSION}

From the findings of the statistical analysis, significant interactions were observed between the factors investigated for the variables remaining seeds, first germination count, abnormal seedlings, dormant and viable seeds. For the variable nonviable seed, the effect was due to isolated factors, whereas for the second count of germination and dead seeds no significant differences were found.

For the variable remaining seeds, the data were fitted to the linear regression model, and was recorded decrease in the seed quantity when the evaluation period was increased, at all the temperatures tested (Figure 1A). Thus, for each day the seed lot reduced the quantity of seeds to 0.55 , 0.69 and $0.48 \%$, at 10,20 and $30^{\circ} \mathrm{C}$, respectively.

This reduction occurred because of some seeds germinated as they had been buried at up to $0.5 \mathrm{~cm}$ depth, which promoted seed germination in horseweed (VIDAL et al., 2007). At this depth the seed is exposed to more light whose incidence is adequate to stimulate germination (YAMASHITA et al., 2016).

One more reason for the emergence of the horseweed seedlings at this depth is the amount of stored reserves, particularly for small seeds (NANDULA et al., 2006), which induces the initiation of the germination process when they are closer to the soil surface or at lower depths. Thus, under such conditions the seeds respond to the light stimulus, which indicates the nearness of the soil surface and the emerged seedling could support the growth until the emergence (CANOSSA et al., 2007).

Generally, no differences were found among the temperatures for all the evaluation periods, thus emphasizing that irrespective of temperature, horseweed seeds in the soil germinate at the same ratio over time. From other studies it is evident that the horseweed seeds can germinate within the 10 to $36^{\circ} \mathrm{C}$ (NANDULA et al., 2006); therefore, emergence is possible at any time of the year, on the soil surface or at the depths nearest to the soil surface (MAIN et al., 2006).

In terms of the first germination count (7 DAS), a percentage decrease was observed at the three temperatures, and the data was fitted to the exponential regression equation at 20 and $30^{\circ} \mathrm{C}$; the data for $10^{\circ} \mathrm{C}$, did not fit to the decreasing exponential model (Figure 1B). At all three temperatures, the germination percentage declined up to day 15 , and tended to stabilize as the evaluation period increased.

Seeds probably were in secondary dormancy, which could be the reason for the low germination values. Reportedly, the horseweed seeds buried at depths of insufficient light can stay quiescent and restart the germination process when the light is suitable (YAMASHITA et al., 2016).

Rapeseed (Brassica napus), which exhibits primary dormancy (KARLSSON \& MILBERG, 2007), reveals that the lack of environmental factors that promote the germination can induce secondary dormancy (MOMOH et al., 2002). Thus, it is believed that the horseweed seeds buried at up to $0.5 \mathrm{~cm}$ depth was sufficient to modify quality of the light and the seeds did not receive the necessary stimulus to germinate; although, study indicates that this depth is sufficient for horseweed seed to germinate (VIDAL et al., 2007).

Regarding the data for abnormal seedlings, it was fitted to the exponential regression model to 20 and $30^{\circ} \mathrm{C}$ (Figure 1C); however, no data adjustment was found to this exponential model for $10^{\circ} \mathrm{C}$. Nevertheless, it is significant the presence of a high percentage of abnormal seedlings at 60 days for 20 and 

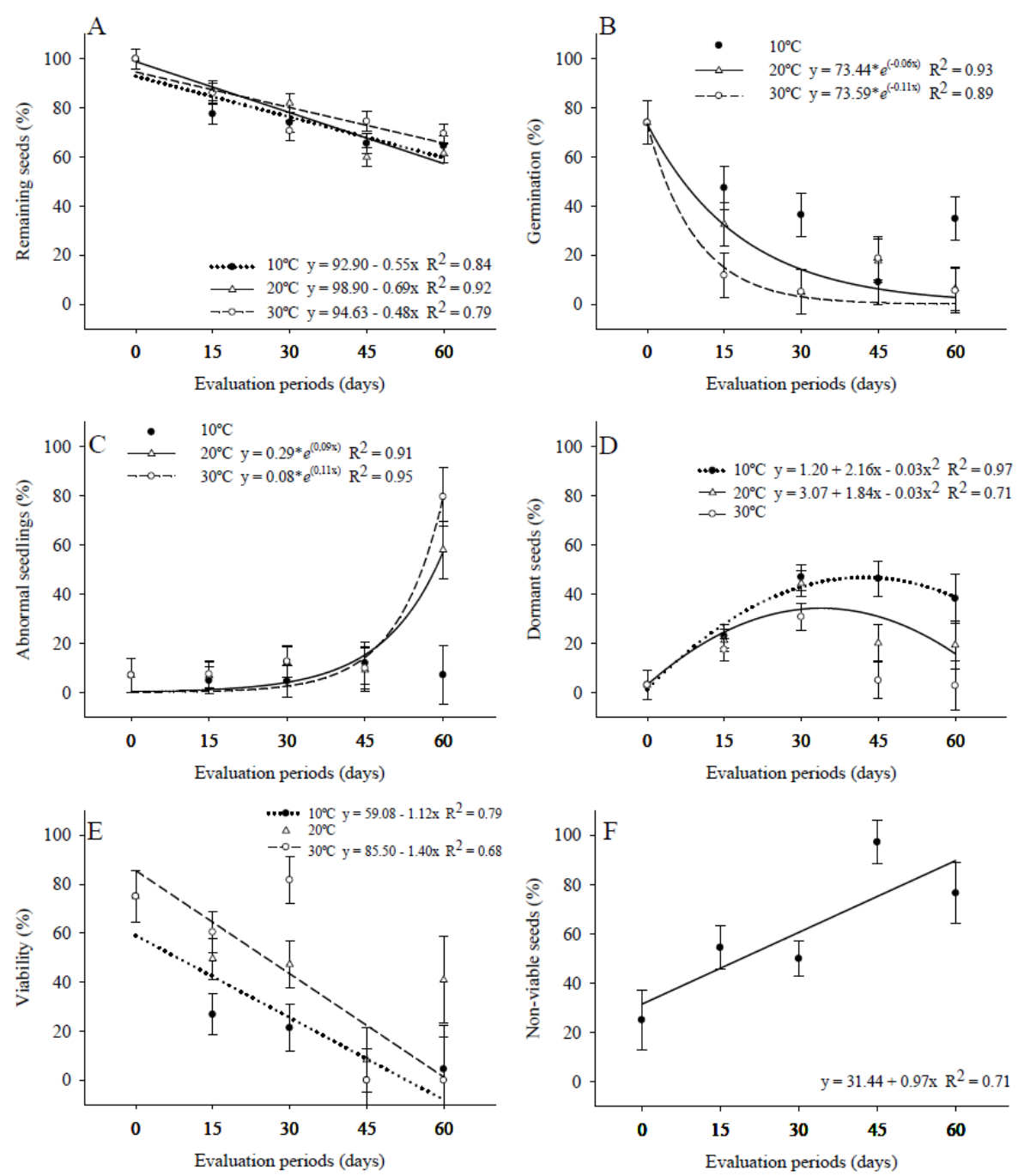

Figure 1 - Remaining seeds (a), first germination count (b), abnormal seedlings (c), dormant seeds (d), viability (e), and non-viable (f) seeds of horseweed (Conyza spp.) as a function of temperature and evaluation periods (days). FAEM/UFPel, Capão do Leão/RS, 2015. Dots represent the mean values of the replicates, while the vertical bars represent the respective confidence intervals of the mean, with $95 \%$ significance.

$30^{\circ} \mathrm{C}$, indicating the deterioration induced by these temperatures (ALHAMDAN et al., 2011). Besides, at $10^{\circ} \mathrm{C}$ a lower percentage of abnormal seedlings were recorded, likely because the seeds decrease their metabolism at low storage temperatures, thus slowing down the deterioration process and raising the longevity (DORIA, 2010).

Concerning about the variable dormant seeds, the data were fitted to a quadratic polynomial regression model for 10 and $20^{\circ} \mathrm{C}$, which the maximum points being achieved at 42 and 34 days, respectively (Figure 1D), and no adjustment was observed to this quadratic model for data from $30^{\circ} \mathrm{C}$.

Percentage of viable seeds decreased in response to the increasing of the evaluation period. The data were fitted to a linear polynomial regression equation, for 10 and $30^{\circ} \mathrm{C}$ (Figure 1E), with 1.12 and $1.40 \%$ decrease per day, respectively. At $20^{\circ} \mathrm{C}$; however, no adjustment of the data to the linear model was detected. 
These findings of dormant and viable seeds verify the behavior observed during the germination, whose germination percentages decreased, meanly because of the secondary dormancy that seeds achieved during the periods of evaluation. Such dormancy is an adaptation to avoid germination during unfavorable environmental conditions for seedling development, as insufficient water, light and/or inadequate temperatures.

The variable non-viable seeds showed a tendency to raise the percentage corresponding to the increase of the evaluation period, and the data were fitted to a linear polynomial regression, registering $0.97 \%$ of increase per day (Figure $1 \mathrm{~F}$ ). After storage or the introduction of the seeds in the soil seed bank, it is normal to observe the effect of deterioration or dead seeds (VIVIAN et al., 2008), which in horseweed is expected to be high, because of the small size of the seed, that contains only a few stored reserves, in consequence a limited longevity (NANDULA et al., 2006).

High percentage of non-viable seeds was detected at $10^{\circ} \mathrm{C}$, greater than the values reported at temperatures of 20 and $30^{\circ} \mathrm{C}$, which showed similarity (Table 1). In some species, low temperatures can compromise the short-term viability of the seeds and thus their longevity, as observed in chili (Capsicum annum $\mathrm{L}$.) when the storage of the seeds was made at $10^{\circ} \mathrm{C}$ or lower temperature (BOONSIRI et al., 2007).

Besides, soaked seeds showed more susceptibility to cold damage, as a result of damage to cell membranes (ROSA et al., 2004), fact that could have happened to the horseweed seeds at $10^{\circ} \mathrm{C}$. However, the high values of non-viable seeds may be linked to the soil depth, as the seeds at the surface or depths nearest to the soil surface are more intensely subjected to the influence of the different environmental factors, as temperature (WESTERMAN et al., 2006).

Table 1 - Non-viable seeds of horseweed (Conyza spp.) after the germination test and different temperatures. FAEM/UFPel, Capão do Leão/RS, $2015^{(1)}$.

\begin{tabular}{lc}
\hline Temperature & Non-viable seeds $(\%)$ \\
$10^{\circ} \mathrm{C}$ & $74 \mathrm{a}$ \\
$20^{\circ} \mathrm{C}$ & $56 \mathrm{~b}$ \\
$30^{\circ} \mathrm{C}$ & $53 \mathrm{~b}$ \\
Coefficient of variation $(\%)$ & 36 \\
\hline
\end{tabular}

${ }^{(1)}$ Means followed by the same lowercase letter in the column do not differ by Duncan's test, at 5\% probability.
Thus, seed exposure at a specific temperature plays an important role to establish the behavior and response of the seed in the future, with a tendency to induce dormancy in seeds expose to relatively low temperatures, whenever this coincide with a specific period of development (MARCOS FILHO, 2015). The author declares that one of the likely reasons to induce dormancy at low temperatures is that the inhibitors of germination are probably synthesized at high temperatures; however, in this study the dormancy was detected in the same way for all the temperatures.

\section{CONCLUSION}

Horseweed seed (Conyza spp.) buried up to $0.5 \mathrm{~cm}$ depth achieves secondary dormancy at temperatures of 10,20 and $30^{\circ} \mathrm{C}$. Seed quality is compromised at 20 and $30^{\circ} \mathrm{C}$ temperatures and the longevity declines, as well.

\section{ACKNOWLEDGEMENT}

The authors extend their gratitude to the $\mathrm{CNPq}$ (National Council for Scientific and Technological Development) and University of Costa Rica (UCR), the "Ministry of Science, Technology and Telecommunications (MICITT)" and "National Council for Scientific and Technological Research (CONICIT)" of Costa Rica, for the financial support extended.

\section{DECLARATION OF CONFLICTING OF INTERESTS}

The authors declare no conflict of interest.

\section{REFERENCES}

ALHAMDAN, A.M. et al. Influence of storage conditions on seed quality and longevity of four vegetable crops. American-Eurasian Journal of Agricultural and Environmental Sciences, v.11, p.353-359, 2011. Available from: <https://www.researchgate.net/ profile/Abdullah_Alhamdan/publication/265811492_Influence of_Storage_Conditions_on_Seed_Quality_and_Longevity_of Four_Vegetable_Crops/links/543c3f620cf2c432f741fe3b.pdf $>$. Accessed: Jan. 17, 2018

BOONSIRI, K. et al. Seed browning of hot peppers during low temperature storage. Postharvest Biology and Technology, v.45, p.358-365, 2007. Available from: <https:/www.sciencedirect. com/science/journal/09255214 >. Accessed: Jan. 17, 2018. doi: 10.1016/j.postharvbio.2007.03.014.

BRASIL. Ministério da Agricultura, Pecuária e Abastecimento. Regras para análise de sementes. Secretaria de Defesa Agropecuária. Brasília: MAPA/ACS, 2009. 395p.

CANOSSA, R.S. et al. Profundidade de semeadura afetando a emergência de plântulas de Alternantheratenella. Planta Daninha, v.25, p.719-725, 2007. Available from: <http://www.scielo.br/pdf/ 
pd/v25n4/a08v25n4.pdf>. Accessed: Mar.12, 2017. doi: 10.1590/ S0100-83582007000400008.

CONSTANTIN, J. et al. Buva: fundamentos e recomendações para manejo. Curitiba: Omnipax, 2013. 104p.

DORIA, J. Generalidades sobre las semillas: su producción, conservación y almacenamiento. CultivosTropicales, v.31, p.74-85, 2010. Available from: <http://scielo.sld.cu/scielo.php?script $=$ sci arttext\&pid=S0258-59362010000100011>. Accessed: Jan. 17, 2018

EMBRAPA. Centro Nacional de Pesquisa de Solos. Sistema brasileiro de classificação de solo. $3^{\mathrm{a}}$ ed. Brasília: Embrapa, 2013. 353p.

HEAP, I.The International Survey of Herbicide Resistant Weeds. 2016. Available from: <http://www.weedscience.com>. Accessed: May. 24, 2017.

KARLSSON, L.M.; MILBERG, P. Comparing after ripening response and germination requirements of Conyzacanadensis and $C$. bonariensis (Asteracae) through logistics functions. Weed Research, v.47, p.433-441, 2007. Available from: <http://onlinelibrary.wiley. com/doi/10.1111/j.1365-3180.2007.00576.x/full>. Accessed: Mar. 11, 2017. doi: 10.1111/j.1365-3180.2007.00576.

LAZAROTO, C. et al. Biologia e ecofisiologia de buva (Conyzabonariensis e Conyzacanadensis). Ciência Rural, v.38, p.852-860, 2008. Available from: <http://www.scielo.br/scielo. php?script $=$ sci_arttext\&pid $=\mathrm{S} 0103-84782008000300045>$. Accessed:Mar. 12,2017. doi: 10.1590/S0103-84782008000300045.

MAIN, C.L. et al. Biotic and abiotic factors influence horseweed emergence. Weed Science, v.54, p.1101-1105, 2006. Available from: $<$ http://www.bioone.org/doi/abs/10.1614/WS-06026R1.1?journalCode=wees $>$. Accessed: Mar.12, 2017. doi: 10.1614/ WS-06-026R1.1.

MARCOS FILHO, J. Fisiologia de sementes de plantas cultivadas. $2^{\circ}$ ed. Londrina: Inovação Distribuidora de Livros Ltda, 2015. 659p.

$\mathrm{MOMOH}$, E.J.J. et al. Variation in the development of secondary dormancy in oilseed rape genotypes under conditions of stress. Weed Research, v.42, p.446-455, 2002. Available from: $<$ http://onlinelibrary. wiley.com/doi/10.1046/j.1365-3180.2002.00308.x/full>. Accessed: Mar. 12, 2017. doi: 10.1046/j.1365-3180.2002.00308.

NANDULA, V.K. et al. Factors affecting germination of horseweed (Conyzacanadensis). Weed Science, v.54, p.898-902, 2006.
Available from: <http://www.bioone.org/doi/pdf/10.1614/WS-06006R2.1>. Accessed: Mar. 12, 2017. doi: 10.1614/WS-06-006R2.1.

TREZZI, M.M. et al. Impact of Conyzabonariensis density and establishment period on soyabean grain yield, yield components and economic threshold. Weed Research, v.55, p.34-41, 2014. Available from: <http://onlinelibrary.wiley.com/doi/10.1111/wre.12125/full>. Accessed: Mar. 12, 2017. doi: 10.1111/wre.12125.

VARGAS, L. et al. Buva (Conyzabonariensis) resistente ao glyphosate na região Sul do Brasil. Planta Daninha, v.25, p.573-578, 2007. Available from: <http://www.scielo.br/scielo. php?script $=$ sci arttext\&pid $=$ S0100-83582007000300017\&lng=en $\& n r m=i s o \& t \operatorname{lng}=p t>$. Accessed: Mar.12, 2017. doi: 10.1590/S010083582007000300017 .

VIDAL, R.A. et al. Impacto da temperatura, irradiância e profundidade das sementes na emergência e germinação de Conyzabonariensis e Conyzacanadensis resistentes ao glyphosate. Planta Daninha, v.25, p.309-315, 2007. Available from: $\quad<\mathrm{http}: / /$ www.scielo.br/scielo.php?script=sci_arttext\&pid $=$ S0100-83582007000200010>. Accessed: Mar.12, 2017. doi: $10.1590 / \mathrm{S} 0100-83582007000200010$.

VIVIAN, R. et al. Efeito da luz e da temperatura na germinação de Alternatheratenella, Conyzabonariensis e Digitaria ciliaris. Planta Daninha, v.26, p.507-513, 2008. Available from: $<$ http://www.scielo.br/scielo.php?script=sci_arttext\&pid $=$ S0100-83582008000300005 $>$. Accessed: Mar. 12, 2017. doi: $10.1590 / \mathrm{S} 0100-83582008000300005$.

WESTERMAN, P.R. et al. Integrating measurements of seed availability and removal to estimate weed seed losses due to predation. Weed Science, v.54, p.566-574, 2006. Available from: $<$ https://www.jstor.org/journal/weedscience>. Accessed: Mar.12, 2017. doi: 10.1614/WS-05-067R.1.

WU, H. et al. Germination, persistence, and emergence of flaxleaf fleabane (Conyzabonariensis [L.]Cronquist).Weed Biology and Management, v.7, p.192-199, 2007. Available from: $<$ http:// onlinelibrary.wiley.com/doi/10.1111/j.1445-6664.2007.00256.x/ full>.Accessed:Mar.12,2017. doi: 10.1111/j.1445-6664.2007.00256.

YAMASHITA, O.M. et al. Germinação de sementes de duas espécies de Conyza em função da presença ou ausência de luz e interação com a adição de nitrato e ácido giberélico no substrato. Ambiência, v.12, p.655-666, 2016. Available from: $<$ http://revistas.unicentro.br/index. php/ambiencia/article/view/1714/pdf>. Accessed: Mar. 12, 2017. doi: 10.5935/ambiencia.2016.02.10. 